\title{
Sondaars' in die tyd van Jesus
}

Henk Pienaaar

Navorser: Departement Nuwe-Testamentiese Wetenskap (Afd A)

Universiteit van Pretoria

\begin{abstract}
'Sinners' in the time of Jesus

The hypothesis which is investigated in this article is that the expression 'sinners' is to be seen as a label for those people who were not socially accommodated within Israelite society in the time of Jesus. This ostracism was religiously legitimated by means of purity regulations with regard to people, places and calendar. The confirmation of the hypothesis provides the historical context of the inscription in Louw \& Nida's semantic dictionary of New Testament Greek with regard to one of the meanings of the word 'sinner' ( $\dot{\alpha} \mu \alpha \rho \tau \omega \lambda$ ós) as 'social outcast'.
\end{abstract}

\section{INLEIDING}

Die hipotese wat in hierdie studie ondersoek word, is dat die uitdrukking 'sondaars' in die tyd van Jesus in sekere omstandighede gebruik is as etikettering van diegene wat nie in die alledaagse Israelitiese samelewing geakkommodeer is nie en dat hierdie ostrasering deur middel van religieuse maatreëls gelegitimeer is. Die bevestiging van hierdie hipotese kan die historiese agtergrond van Louw \& Nida (1988:774) se omskrywing

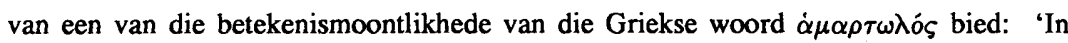
contexts such as Mk 2.17, Mt 9.10, Lk 15.2, etc., $\dot{\alpha} \mu \alpha \rho \tau \omega \lambda o ́ s$ may refer to persons who were irreligious in the sense of having no concern for observing the details of the law. Such people were often treated as social outcasts' (my beklemtoning).

Die bedoeling van die studie is met ander woorde om 'n saak daarvoor te probeer uitmaak dat 'sondaars' in die tyd van Jesus onder andere na mense verwys het wat as sosiaal veragebeskou is omdat hulle vir die samelewing 'n soort bedreiging ingehou het. Die bedreiging kan byvoorbeeld aan natuurlike oorsake toegeskryf word, soos om aan 'n aansteeklike siekte te ly of die bedreiging kan militêr, polities of ekonomies van aard

* Hierdie artikel is 'n verwerking van die resultate van die M Div-skripsie, ingedien en aanvaar as deel van die vereistes vir die M Div-graad (1994), Departement Nuwe-Testamentiese Wetenskap, Fakulteit Teologie (Afd A), Universiteit van Pretoria, onder leiding van prof dr A G van Aarde. 
wees. Sosiaal-veragtes het in die tyd van Jesus, volgens die persepsie van verskeie groepe in eerste-eeuse Judaïsme (bv die Saddusese, Esseense en Farisese), nie ingepas in sowel die simboliese as die sosiale wêreld nie. So byvoorbeeld het iemand met 'n liggaamsgebrek nie in die wêreld van die volmaakte God van Israel ingepas nie. Die oorsaak van die gebrek is religieus verstaan en is derhalwe toegeskryf aan een of ander oortreding van Goddelike (skriftuurlike) voorskrifte. Hierdie godsdienstige legitimering van sosiale ostrasering het ingehou dat die 'sondaars' nie aanspraak kon gemaak het op God se teenwoordigheid in hulle lewe nie. Die implikasie hiervan is dat die 'sondaars' onder andere belangrike religieuse voorregte ontbeer het (soos bv die toegang tot die tempel), beskou is as mense wat die wil van God oortree (en dus wetteloos is) en beskuldig is van goddeloosheid.

Volgens Van Aarde (1994:118) het die Fariseërs se ideologie veral gewentel om die strewe om die tempelgemeenskap in die alledaagse lewe van Israeliete te repliseer. Dit het die religieuse implikasie gehad dat sosiale ostrasering gelegitimeer is met die verklaring van Godsvervreemding. Dit wil sê, die marginalisering van sommige mense in die samelewing is geregverdig deur die verduideliking dat hulle ook nie toegang tot God in die tempel of sinagoge sou gehad het nie:

Onrein en onvolmaakte mense, dinge en plekke is, met ander woorde, gesien as behorende tot buite die domein van die koninkryk van God. Sulke mense van sulke plekke wat hulle met sulke dinge bemoei, is die 'sondaars' wat in die mag van demone is.

(Van Aarde 1994:118)

Jesus se prediking oor die tema 'vergifnis van sonde' het klaarblyklik die bedoeling gehad dat 'vergifnis' daarin sou konkretiseer dat 'sondaars' nie net deur God aanvaar is om in sy teenwoordigheid te kom nie, maar ook om in die samelewing geakkommodeer te word deur ' $n$ plek in die sosiale wêreld te ontvang. Aanvaarding in die Israelitiese gemeenskap gaan dialekties hand in hand met die Israeliet se ervaring van God se teenwoordigheid in sy/haar lewe. Jerome Neyrey (1986:110) stel dit soos volg:

... Jesus used his influence to lead marginal people across boundaries which classified them as unclean, outsiders, sinners into a new role as forgiven, restored, chosen members of God's covenant group.

Volgens Marcus Borg $(1988,1991)$ is twee kenmerke van die renaissance in Jesusnavorsing sedert die tagtigerjare besonder opvallend: eerstens die vraag of Jesus ' $n$ 
eskatologiese boodskap gehad het of nie en tweedens die ondersoek na aspekte van die sosiale wêreld van eerste-eeuse Palestina. Borg meld dat 'n vorige konsensus onder Nuwe-Testamentici wat Jesus as die vervuller van die rol van 'n eskatologiese profeet gesien het en sy sending en boodskap binne die raamwerk van 'n nabye eskatologie geïnterpreteer het, begin verkrummel. ' $n$ Nie-eskatologiese verstaan van Jesus is besig om na vore te tree. So ook 'n nie-objektveerde en 'n hierdie-wêreldse verstaan van eskatologie:

Jesus did not proclaim the imminent end of the world of ordinary history. It is best, therefore, to specify what is meant by the phrase 'noneschatological Jesus.' The contrast is specifically to the image of Jesus as one who proclaimed the imminent coming of the Kingdom of God and the Son of Man, understood as involving the last judgement and the end of human history as we know it. That, according to the emergent consensus, was neither Jesus' expectation nor message.

(Borg 1988:287)

Die ontdekking, publikasie en analise van nuwe argeologiese en manuskripmateriaal asook die gebruik van metodes en modelle van ander dissiplines, soos die sosiale wetenskappe, kulturele antropologie en die geskiedenis van godsdienste, het ons verstaan van die sosiale wêreld van die eerste-eeuse Palestina verbreed. Ons ken nie net meer feite nie, maar ons verstaan die dinamiek van die wêreld van die eerste-eeuse Palestina beter. In hierdie studie word daar na aanleiding van bogenoemde twee kenmerke van hedendaagse Jesus-navorsing waarna Borg verwys, ingegaan op Jesus se houding ten opsigte van sondaars. Ter wille van selfkritiek en kruiskontrole begin ek my ondersoek by 'n beskrywing van die standpunt van 'n gespreksgenoot van Marcus Borg wat nie met Borg saamstem oor die sogenaamde 'nie-eskatologiese' Jesus nie, te wete E P Sanders. Ek konsentreer egter net op Sanders se oortuiging met betrekking tot Jesus se houding jeens die 'sondaars'. Vir die doeleindes van die studie gaan ek nie in op die kriteria wat sowel Borg as Sanders (maar ook ander Jesus-navorsers) aanwend om die Jesus van die geskiedenis te (re)konstrueer nie. Wanneer ek na Jesus in hierdie studie verwys, bedoel ek die historiese Jesus in 'n nie-positivistiese sin. My ondersoek val in drie hoofstukke uiteen:

* E P Sanders se beskouing oor die 'sondaars', soos hy dit beskryf het in sy boek Jesus and Judaism, word aan die orde gestel. Die bedoeling hiermee is om aan te 
dui dat Sanders se ondersoek - teen die agtergrond van my eie vraagstelling belangrike insigte bevat, maar nie die implikasie daarvan vir die eerste-eeuse sosiale wêreld uitgewerk het nie.

* In die lig van die navorsing met betrekking tot die sosiale wêreld van die eersteeeuse Palestina word, soos ek in die vraagstelling daarop gewys het, die sondaars beskryf as diegene wat nie in die normale sosiale samelewing geakkommodeer is nie.

* $\quad \mathrm{Na}$ aanleiding van die voorafgaande beskrywing vertrou ek om in my gevolgtrekking aan te toon dat Jesus se prediking oor 'vergifnis van sonde' daarin wou konkretiseer dat 'sondaars' as sosiale uitgestotenes weer in die gemeenskap ingebring word en 'n plek in die sosiale wêreld kry, omdat hulle wel God se teenwoordigheid in hulle lewe ervaar.

\title{
2. DIE INSIGTE VAN E P SANDERS
}

\section{1 'Sondaar wees' en 'verag wees'}

Volgens Sanders in sy boek, Jesus and Judaism, is die onderskeidende kenmerk van Jesus se boodskap oor die koninkryk van God dat dit 'sondaars' insluit. 'n Mens kan dit sterker stel: die belofte van redding aan 'sondaars' is die mees beslissende kenmerk van Jesus se boodskap. In die betrokke werk het Sanders (1985:176) in debat getree met Joachim Jeremias oor die vraag wie die 'sondaars' in werklikheid was. Volgens Jeremias is die sondaars die עם הארצ, die 'volk van die land'. Hy stel dit soos volg:

\begin{abstract}
Summing up, then, we can now say that Jesus' following consisted predominantly of the disreputable, the עם הארצ, the uneducated, the ignorant, whose religious ignorance and moral behaviour stood in the way of their access to salvation, according to the convictions of the time.
\end{abstract}

(Jeremias 1978:112)

Uit die werk van Jeremias (1978) blyk dit dat daar in die Joodse sondebegrip 'n verband bestaan tussen die oortreding van die wet, verag wees, tollenaar wees, heiden wees en om 'sondaar' en 'duiwelbesete' genoem te word. Sanders aan die ander kant meen egter dat die oortuiging van Jeremias (1978:112) dat die groepering wat bekend staan as die 'gewone mense' (die עם הארצ), betrekking sou hê op die term 'sondaars', 
nie korrek is nie. Hy wys daarop dat die woord $\dot{\alpha} \mu \alpha \rho \tau \omega \lambda$ oi die Hebreeuse woord veronderstel. רשעעימ רשימ is 'n tegniese term wat verwys na diegene wat opsetlik en afskuwelik gesondig het, dit wil sê die goddeloses wat hulle nie bekeer nie. Volgens Sanders kan die 'goddeloses' in 'n sekere sin as die 'professionele sondaars' beskou word.

Die term 'sondaars' verwys volgens Sanders (1985:177) na mense wat oor die algemeen in hulle daaglikse sake die wet oortree. Uit Levitikus 25:36-38 is dit byvoorbeeld duidelik dat diegene wat God vrees, mense is wat byvoorbeeld nie rente van hulle mede-Israeliet vra nie. Diegene wat rente vra, vrees nie God nie. Hulle lewe dus 'goddeloos'. Op die keper beskou, is 'sondaars' mense wat hulle rug op God gekeer het. Sanders (1985:178) formuleer dit soos volg:

Thus we know in general terms who the wicked were, and we can readily understand why 'tax collectors' and 'sinners' go together in several passages in the Gospels: they were all traitors. Tax collectors, more precisely, were quislings, collaborating with Rome. The wicked equally betrayed the God who redeemed Israel and gave them his law. There was no neat distinction between 'religious' and 'political' betrayal in first-century Judaism.

Dit is so, volgens Sanders (1985:178), dat Jesus sy sending gesien het as 'n sending na die 'verlorenes' en die 'sondaars'. Dit was dus 'n sending na die 'goddeloses'. Tog was die klag teen Jesus tydens sy verhoor nie dat Hy Hom met die 'gewone mense' bemoei het nie. Die konflik wat daar tussen Jesus en die godsdienshoofde was, was oor die status van die 'goddeloses'. Dit is volgens Sanders (1985:179) 'n fout om te dink dat die Fariseërs ontsteld was omdat Jesus die gewone eenvoudiges en die ekonomiese armes bedien het.

Teenoor Jeremias (1978:112) se opvatting is daar volgens Sanders geen getuienis dat die 'sondaars' betrekking het op die עם הארצ nie. Die Rabbynse materiaal wat heelwat later as die Nuwe Testament gedateer word en nie in die Nuwe Testament ingelees kan word nie, is die enigste bron waar ons 'n aanduiding kry van die Farisese houding teenoor die 'gewone mense'. Sanders (1985:180) stel dit soos volg:

I maintain that there is absolutely no passage in the entirety of that literature which in any way supports the assertion that the scrupulous and learned regarded the ordinary people as 'the wicked', those who flagrantly and persistently disobeyed the law. 
Dit is egter nie onrealisties om te aanvaar dat daar voor en na $70 \mathrm{n} \mathrm{C}$ sekere vyandigheid tussen die sosiale toplaag van die samelewing en die 'gewone mense' was nie (Sanders 1985:180). Maar die gevoel van vyandigheid het nie' gelei tot 'n sekere siening aan die kant van die Fariseërs dat die 'gewone mense', die עם הארצ, afgesny is van die redding van God nie. Daar word wel algemeen aanvaar dat daar voor $70 \mathrm{n} \mathrm{C}$ חברימ (persone wat 'n hoë standaard van reinheid gehandhaaf het) was en dat hulle onder andere skrifgeleerdes vanuit die party van die Fariseërs ingesluit het (vgl Van Aarde 1994:190). Daar is egter geen rede om te vermoed dat hierdie mense hulleself as 'regverdig' gesien het en die res van Israel as 'goddeloos' nie.

Die 'gewone mense' moet dus nie sonder meer as ongodsdienstig beskou word nie. Hulle het heel waarskynlik die grootste gedeelte van die wet onderhou, die feeste gevier en die belangrikste reinheidsvoorskrifte onderhou. Volgens Sanders was 'onrein persone' met ander woorde nie per se as 'sondaars' gesien nie. Die verskil tussen Jeremias en Sanders fokus dus op die konnotasie van die konsep 'veragtes'. Die veragtes by Jeremias is die gewone mense, die עם הארצ. Die veragtes by Sanders is spesifiek die oortreders van die wet.

\subsection{Reinheid}

Die gevolgtrekking waartoe ons in die lig van Sanders se standpunt moet kom, is met ander woorde dat onreinheid as sodanig nie 'n persoon 'n sondaar gemaak het wat nie weer met God versoen kon word nie. Verder het dit ook nie 'n persoon ongeskik vir tafelgemeenskap gemaak nie. Sanders sien derhalwe nie dieselfde verband raak wat iemand soos Neusner (1974:47) meen daar tussen eerste-eeuse Jode se beklemtoning van tafelgemeenskap en tempel toe gaan bestaan nie. 'n Studie van die reinheidsmaatreëls bring volgens Sanders wel die volgende resultate na vore:

* Onreinheid is nie altyd toe te skryf aan 'n oortreding van 'n gebod nie. Of dit die geval was of nie, by beide gevalle - onreinheid as sodanig en wetsoortreding was 'n reinigingshandeling wel 'n vereiste voordat die tempel binne gegaan kon word. Dit is wel as sonde beskou wanneer 'n onrein persoon 'heilige kos' eet of die tempel binnegaan.

* 'n Reinheidsoortreding wat wel as sonde beskou is, is byvoorbeeld die eet/drink van bloed. 
* Kontak tussen 'n rein en 'n onrein persoon het ook nie op sonde neergekom nie, behalwe seksuele omgang met 'n vrou wat menstrueer. Sulke kontak is egter vermy, sodat onreinheid nie versprei of mans dalk by hulle tempel toe gaan enige iets van die tempeltoebehore sou aanraak nie.

* As 'n algemene reël kan egter aanvaar word dat persone wat onrein geword het, nie beskou is as mense wat gesondig het nie. Normale menslike verhoudings is derhalwe nie noemenswaardig deur 'onreinheid' geaffekteer nie. Die onderhouding van die reinheidsvoorskrifte was gevolglik nie net die ideaal van die Fariseërs nie. Hierdie voorskrifte is wyd deur ook ander groepe binne die Judaïsme onderhou.

As persone die reinheidswette verontagsaam het en hulleself nie gereinig het nie, was hulle voortdurend as onrein beskou. In so 'n geval is dit redelik om te aanvaar dat hulle 'sondaars' was in die sin van 'goddeloos wees' omdat sulke persone 'n siening gehad het dat Goddelike (skriftuurlike) voorskrifte nie nagekom hoef te word nie. Sanders (1985:184) formuleer sy standpunt oor hierdie saak soos volg:

Not intending to be observant is precisely what makes one 'wicked'; but the wickedness comes not from impurity as such, but from the attitude that the commandments of the Bible need not be heeded .... Thus, these biblical purity laws, which most people seem to have observed, did not lead to a fixed view that the common people were sinners.

Met ander woorde, alhoewel onreinheid per se nie 'n persoon 'n 'sondaar' gemaak het nie, het voortdurende onreinheid dit wel gedoen. In die evangelies is daar aanduiding daarvan dat sekere gewone Jode hulle hande gewas het voordat hulle geëet het. Handwassing as sodanig is egter nie 'n Skriftuurlike eis nie. Die gebod kom wel in die Mishna voor en is dus 'n voorskrif wat binne die raamwerk van die 'Rabbynse Judaisme' - wat 'n ná-Nuwe-Testamentiese beweging is - gegeld het. Neusner se baanbrekerswerk om die oorspronge van baie van die Rabbynse tradisies in die Farisese Judaïsme van die Herodiaanse en selfs Hasmoniese periodes terug te vind, word egter wyd deur vakkenners erken (kyk Van Aarde 1994:107 vir 'n omskrywing van hierdie periodes). Alhoewel daar onsekerheid bestaan oor die geskiedenis van die maatreëls met betrekking tot die seremoniële handwassing voor maaltye, is sekere sake in hierdie verband wel duidelik. Dit is nie 'n reinheidswet wat as sodanig in die Ou Testament 
voorkom nie. Dit was 'n gebruik wat in die tyd van Jesus deur veral die Fariseërs ontwikkel en beklemtoon is. Neusner (1974:47) maak die belangrike opmerking dat die gemeenskaplike maaltyd vir die Fariseër die replika van die rituele handeling in die tempel geword het: ' $\ldots$ in classical Judaism the table at which meals were eaten was regarded as the equivalent of the sacred altar in the Temple. Judaism taught that each Jew before eating had to attain the same state of ritual purity as the priest in the sacred act of making a sacrifice'.

Maar volgens Sanders het gehoorsaamheid aan die reinheidswette nie die toelating tot die tafelgemeenskap van die Jode beïnvloed nie, maar wel verband gehou met die toegang tot die tempel. Soos ons hierbo gesien het, wys Neusner (kyk ook Elliott 1991; Van Aarde 1994) op die verband wat daar tussen die alledaagse lewe van eersteeeuse Jode en hulle tempelbeskouing bestaan het en hiervolgens sou reëls met betrekking tot die tempelgemeenskap ook die reëls met betrekking tot die alledaagse tafelgemeenskap bepaal het. Ons het gesien dat die konsekwensie van Sanders se standpunt daarop neerkom dat onreinheid as sodanig nie die Jood tot sondaar sou maak nie. Dit het volgens Sanders 'n mens net 'n nie- חבר gemaak, maar volgens Neusner kom hierdie insig daarop neer dat só ' $n$ onreine in terme van 'normatiewe Judaïsme' as deel van die עם הארצ beskou sou word. Die term 'normatiewe Judaïsme' verwys na daardie Joodse groepe wat hulle totale lewe volgens die Mosaïese wet laat beheers het en met wie mense soos Paulus in konflik gekom het. Die onderskeid wat Sanders in die lig van bogenoemde standpunt tussen die deelhê aan die 'tafelgemeenskap' in die huis en die 'offergemeenskap' in die tempel tref, staan dus in skerp kontras met Neusner se oortuiging dat die tempelmaatreëls ten minste deur die Fariseërs na die alledaagse huishoudings uitgebrei is en dat die regulasies met betrekking tot die 'tempelgemeenskap' (toelating en dies meer) op dié wyse in die 'tafelgemeenskap' van die Jood gerepliseer is - of ten minste deur die Fariseërs as ideaal vir die volk voorgehou is.

\subsection{Toegang tot die Israelitiese tempelgemeenskap}

Dit is dus volgens Sanders nie korrek om te meen dat die 'gewone mense' binne die verwysingsraamwerk van 'normatiewe Judaïsme' uitgesluit sou gewees het van die redding van God nie. Sulke 'uitgestotenes' is die 'goddeloses' en die term 'goddeloses' het nie spesifiek betrekking gehad op die 'gewone mense' nie. Dit het ook nie in die periode van die 'formatiewe Judaïsme' plaasgevind nie. Hierdie periode verwys na die Farisese hervorming wat in die periode na die vernietiging van die tempel in $70 \mathrm{n} \mathrm{C}$ die opkoms van die 'Rabbynse Judaïsme' voorafgegaan het. Volgens Sanders het die Fariseërs nie voor die voet alle ander mense buite hulleself om van God se redding uitgesluit nie. 
Sanders (1985:190) meen dat ons verstaan van die werklike situasie sal verbeter indien ons die 'gewone mense' (die עם הארצ) sien as diegene wat gedurende die 'Rabbynse Judaïsme' beskou is as mense met 'n gebrek aan opvoeding in die wet en nie as spesifiek diegene wat die reinheidsmaatreëls nie nagekom het nie. Die Rabbyne het nie van die gewone mense verwag om alles wat hulleself van die wet geweet het, self te ken nie. Maar wat was die situasie gedurende die periodes van die 'normatiewe Judaisme' en die 'formatiewe Judaïsme'? Dit wil volgens Sanders voorkom asof die skrifgeleerdes (חברימ), net soos in die geval van die rabbi's gedurende die periode van die 'Rabbynse Judaïsme', nie die sogenaamde 'onopgevoedes' voor die voet as 'sondaars' gesien het nie. Soos ons gesien het, wys Sanders daarop dat die 'gewone mense' nie verplig was om alles te weet wat die skrifgeleerdes geweet het nie. Hierdie standpunt bots egter met wat Sanders self met betrekking tot 'n opmerking van Josefus ( $A P$ II.177) uitwys, naamlik dat die Jode teenoor die ander volke uitstaan omdat hulle hulle wette so goed ken. Volgens Sanders (1985:191) is dit logies om in te sien dat oningeligte mense nie noodwendig die wet meer oortree as die ingeligtes nie. Sanders tref egter nie 'n onderskeid tussen die vlak van wetskennis en die eis van onverbiddelike gehoorsaamheid aan die voorskrifte van die wet nie.

Daar kan volgens Sanders ook nie beweer word dat diegene wat nie die priesterlike reinheidmaatreëls nagekom het nie, buite God se genade te staan sou gekom het nie. Die lees van die Mishna mak dit duidelik dat die rabbi's nie die oortreding van die reinheidswette as sodanig as sonde gesien het nie, maar - soos ons reeds vroeër daarop gewys het - eerder die voortdurende verontagsaming van die voorskrifte in hierdie verband. Ons het ook daarop gewys dat 'n onrein persoon in die periode van die 'normatiewe Judaïsme' nie in die tempel mag ingegaan het nie en dit het ook die sinagoges gedurende die periodes van sowel die 'formatiewe' as die 'Rabbynse Judaisme' gegeld.

Wat die uitsluiting uit die sosiale en godsdienstige gemeenskap ten tye van Jesus met ander woorde gedurende die periode van 'normatiewe Judaïsme' - betref, het ons gesien dat dat die nברימ 'n spesiale gedragskode onderhou het wat hulle volgens Sanders nie van buitestaanders verwag het nie. Verder het die חברימ hulle nie soos die Esseners van Jerusalem onttrek nie. Solank hulle daar gebly het en in die tempel aanbid het, het hulle nie gedink dat ander Israeliete daarvan afgesny is nie. Deur in Jerusalem te bly en daar te aanbid, het hulle getoon dat hulle nie die minder 'strenges' as buite die Israelitiese verbond geag het nie. Dit was buitendien nie binne die mag van óf die חברימ of die Fariseërs om die gewone mense uit die sosiale en godsdienstige gemeenskap uit te sluit nie - bloot omdat hulle nie in beheer daarvan was nie. Die priesters het dit beheer. 
We should remember that, before 70, the עם הארצ were primary members of 'normative Judaism', along with the priesthood. According to the dominant 'conviction of the time', that of the common people and the priesthood, the former were worthy members of Israel. Both groups doubtless thought that, as long as people participated in the worship of the temple, repented on the Day of Atonement, and did the other things prescribed in the Bible for the correction of sin and the removal of impurity, they were fully members of the social and religious community.

(Sanders 1985:193)

Volgens Sanders het die Fariseërs ook nie die sinagoges beheer nie. Sanders wys verder daarop dat naas die tempel en die sinagoge, die huis die ander fokuspunt van die Joodse godsdienstige lewe was. Hiermee wil hy die relatiewe onafhanklikheid van die 'gewone mense' met betrekking tot die Fariseërs beklemtoon. Die vrome gewone mense het definitief die Paasfees, Loofhuttefees en ander feeste gevier. Ons kan aanneem dat hulle hulleself gesien het as mense wat ten volle deelgeneem het aan die nasionale godsdiens. Alle feite dui volgens Sanders daarop dat die Fariseërs nie vyandig was teenoor die insluiting van die gewone mense in die koninkryk van God nie. Weer eens neem hy egter nie die Farisese ideologie in ag nie waarvolgens 'die voorskrifte rakende reinheid by die gemeenskaplike maaltyd, dit wil sê die akkommodering in die huishouding, dieselfde was as dié wat gegeld het om toegang tot die tempel te reël' (Van Aarde 1989:18).

\subsection{Vergifnis en bekering}

Sanders (1985:200) wys daarop dat vakkenners soos Norman Perrin Jesus se aankondiging van genade en vergifnis aan sondaars beskou as die belangrikste rede van die klag teen Jesus wat op sy verhoor en kruisiging uitgeloop het. Hierdie beskouing is egter volgens Sanders om die volgende redes nie korrek nie. Eerstens was die aankondiging van vergifnis nie uniek in Judaïsme nie. Tweedens het die tollenaars en sondaars geweet hoe om vergifnis te verkry. Derdens het Jesus nie die mense terugverwelkom in die gemeenskap nie, want Hy het nie die toegang tot die gemeenskap beheer nie. Vierdens was Jesus nie 'n bekeringsprediker (soos Johannes die Doper) nie. Sanders (1985:203) formuleer sy standpunt soos volg: 
Jesus doubtless believed in reconciliation between the wicked and God, but the absence of passages which call for repentance and restitution shows at least that he did not aim at restoring the wicked to the community.

Dit is ook volgens Sanders belangrik om te onthou dat niemand in die Israelitiese gemeenskap kwaad sou gewees het as Jesus 'sondaars' en 'renegate' bekeer het nie. Wat was dan volgens Sanders aanstootlik aan Jesus se gedrag? Ons het gesien dat dit volgens Sanders nie Jesus se boodskap oor die vergewing van bekeerde sondaars kan gewees het nie. Hierdie vergewing was nie uniek nie en dit sou ook nie aanstoot gegee het nie. 'n Ander oplossing wat volgens Sanders (1985:204) aangebied word, is dat Jesus vergewing geskenk het voordat daar aan die eis om bekering voldoen is. In die Judaïsme is vergewing net gegee aan diegene wat 'regverdig' geword het. Hulle moet met ander woorde eers 'regverdig' word, voordat hulle vergewe is. Daarom moet daar byvoorbeeld eers aan die reinheidsvoorskrifte voldoen gewees het.

Hierdie aangeleentheid het met 'n kronologiese onderskeid te doen. Jesus se vergewing het vereis dat mense hulle bekeer. Judaïsme het vereis dat mense hulle bekeer en dan sal hulle vergewe word. Oortredings teenoor 'n medemens het kompensasie sowel as bekering vereis. Vir ander oortredings moet persone hulle net bekeer het. Bekering is in sulke gevalle gedemonstreer met die bring van 'n offer in die tempel en dit het nie kompensasie vir die geaffekteerde ingehou nie. Sanders meen dat die 'uniekheid' en die 'aanstoot' van Jesus se boodskap verband hou met die verskil in perspektief tussen 'normatiewe Judaïsme' en Jesus met betrekking tot sondaar wees en vergewe wees:

He may have offered them inclusion in the kingdom not only while they were still sinners but also without requiring repentance as normally understood, and therefore He could have been accused of being a friend of people who indefinitely remained sinners ... I propose, then, that the novelty and offence of Jesus' message was that the wicked who heeded him would be included in the kingdom even though they did not repent as it was universally understood - that is, even though they did not make restitution, sacrifice, and turn to obedience to the law.

(Sanders 1985:207; my beklemtoninng) 
Jesus se saam eet met tollenaars en sondaars kan gesien word as 'n teken dat hulle volgens Jesus in die komende koninkryk ingesluit kan word, net soos die tempel vir hulle oop staan sonder dat daar noodwendig aan die reinheidsvoorskrifte voldoen is. Juis hierdie saak figureer volgens Sanders in die gelykenis van die Fariseër en die tollenaar (Luk 18:9-14). In hierdie gelykenis erken die tollenaar teenoor God dat hy nog 'n sondaar is, terwyl hy homself in die tempel bevind. Die Fariseër aan die ander kant dank God dat hy regverdig is en nie soos die tollenaar 'n sondaar is nie. Die veronderstelde selfaanspraak van Jesus om te weet wie God in die koninkryk insluit en wie nie en die degradering van die normale wyse van geregtigheid, het Jesus uiteraard in konflik met 'normatiewe Judaïsme' gebring.

\subsection{Gevolgtrekking}

Die volgende sake kom op grond van Sanders se bespreking na vore:

* Die sondaars is nie maar net die 'gewone mense', die עם הארצ, nie, maar persone wat hulle rug op God gekeer het deur nie die Skriftuurlike voorskrifte te gehoorsaam nie. By sulke mense is God nie teenwoordig nie.

* Die ostrasering van sondaars in die Joodse samelewing het in die grond van die saak daarop neergekom dat hulle toegang tot die tempel geweier is. Om hierdie weiering te reguleer was maatreëls nodig. Die reinheidswette was die regulasies wat die toegang beheer het.

* Jesus is deur die priesterhoofde verwerp en selfs doodgemaak nie op grond van die feit dat Hy sondaars vergifnis aangebied het nie, maar op grond daarvan dat $\mathrm{Hy}$ verkondig het dat God sondaars onvoorwaardelik aanvaar nog voordat daar berou getoon is.

* Sanders lê sterk klem op Jesus se Joodsheid. Jesus se beskouing van die nabye (imminente) eskatologie - wat volgens Sanders sentraal in Jesus se eie selfverstaan en boodskap is - het tot gevolg dat vergifnis van sonde vir Jesus beteken het dat sondaars in die komende ryk van God ingesluit word sonder dat daar noodwendig iets van hulle konkrete sosiale situasie verander het of hoef verander het.

* Die tekortkoming van die insigte van Sanders is dat hy die Joodsheid van Jesus ideologies vervlugtig deur dit hoofsaaklik binne die teoretiese voorstellingswêreld van die eskatologie te verstaan en dit nie konkretiseer in terme van die sosiale 
strukture van die betrokke tyd nie. Sanders se konstruksie van die historiese Jesus gaan mank aan 'n deurdringende literêr-historiese en sosiaal-wetenskaplike ondersoek. Jesus-navorsers wat hiermee erns maak, is oortuig daarvan dat outentieke Jesus-uitsprake, sover as wat dit literêr-histories gekonstrueer kan word, nie apokaliptiese tendense bevat nie. Hierbenewens het Nuwe-Testamentici wat die sosiale wêreld van eerste-eeuse Palestina aan die hand van teorieë en modelle in die sosiale wetenskappe ondersoek het, tot die gevolgtrekking gekom dat Jesus se tempelkritiek verband hou met die repliseringstrategie van die Fariseërs wat die maatreëls met betrekking tot die tempelgemeenskap uitgebrei het na die familiale tafelgemeenskap. Sanders skei verkeerdelik die tempelgemeenskap te sterk van die tafelgemeenskap in die alledaagse huishouding.

\section{ASPEKTE VAN DIE SOSIALE WÊREL VAN EERSTE-EEUSE PALES- TINA}

Teenoor Sanders wat Jesus se verhouding tot sy sosiale wêreld as iets abstraks ideologies - sien, is daar geleerdes soos Borg, Horsley en Schlüsser-Fiorenza wat Jesus se verhouding tot sy sosiale wêreld nie net as baie konkreet ag nie, maar inderdaad as die sentrale aspek van die Joodsheid van Jesus sien. '... Borg's interpretation of Jesus is based on an understanding of his teaching in a particular historical setting created by the social, political, and economic aspects of the Roman occupation' (Smith 1989:74).

Borg beskou Jesus as in konflik met die dominante etos en institusies van die sosiale wêreld van sy dag. Volgens hom is Jesus die 'stigter' van 'n binne-Joodse hernuwingsbeweging met ' $n$ alternatiewe visie op die Joodse lewenswyse en gemeenskap: 'Thus, though they (Fiorenza, Borg, Horsley) affirm that Jesus advocated a transformation that engaged the social structures of his day, they see Jesus as a definitely Jewish voice within Judaism (Borg 1991:9). Sentraal in hierdie siening is die verstaan van die kulturele dinamiek van die sosiale wêreld waarin Jesus Hom bevind het. Tans word dit algemeen aanvaar dat daar nie 'n uniforme Judaïsme in die eerste-eeu was nie. Dunn (1991:18) maak egter die volgende opmerking:

Nevertheless, all that being said, we can still speak of a common and unifying core for second Temple Judaism, a fourfold foundation on which all these diverse forms of Judaism built, a common heritage which they all interpreted in their own ways. 
Volgens Dunn (1991:18) is die volgende vier sake pilare van die Judaïsme van die tweede tempelperiode: monotheissme, uitverkiesing, verbond gefokus in die tora en land gefokus in die tempel. Een van hierdie pilare, wat belangrik vir hierdie studie is, is land gefokus in die tempel. Volgens Dunn beklemtoon hierdie pilaar die rol van die tempel as sentrum van Israel se nasionale en godsdienstige lewe van daardie tyd. Ons kyk vervolgens na die kulturele dinamiek van Jesus se sosiale wêreld soos verstaan deur die Judaïsme van die tweede tempelperiode.

\subsection{Aspekte van die simboliese universum van eerste-eeuse Palestina}

Van Staden (1991:94) definieer die term 'simboliese universum' as 'that body of theoretical tradition about the "ultimate reality". Berger \& Luckmann (in Van Staden 1991:95) sê in hierdie verband dat 'the symbolic universe orders and thereby legitimates everyday roles, priorities, and operating procedures by placing them sub specie universi, that is, in the context of the most general frame of reference conceivable'. Die simboliese universum van eerste-eeuse Palestina is dus ' $n$ breë en algemene teoretiese konsep wat gespesifiseer kan word deur ses gebiede in die sosiale wêreld van eerste-eeuse Palestina te bestudeer:

* Reinheid: patrone van orde en klassifikasie.

* Rites: rituele om grense te vorm en in stand te hou of seremonies wat waardes en institusies bevestig.

* Liggaam: die sosiale persepsie van die menslike liggaam.

* Sonde: die sosiale definisie van sonde en afwyking.

* Kosmologie: wie is in die wêreld en wie doen wat.

* Bose en ongeluk: hoe word dit verduidelik?

Verskillende kultuurgroepe sal met ander woorde in die lig van bogenoemde definisie van die term 'simboliese universum' eiesoortige antwoorde gee op vrae wat met die bepaalde sesdeling verband hou. Bepaalde kultuurgroepe se simboliese universum word dus deur onder andere tyd, plek, etnisiteit en sosiale status gekondisioneer. Malina (1986:20) gebruik die kruis-kulturele model van onder andere Mary Douglas as 'n makromodel om die simboliese en sosiale universums van die Nuwe Testament te verduidelik. Met behulp van hierdie model kan ons in navolging van Neyrey (1986: 107.) die simboliese universum van 'normatiewe Judaisme' in die tyd van Jesus soos volg beskryf: 


\section{* Reinheid:}

Judaïsme in die tyd van Jesus word veral daardeur gekenmerk dat orde in die sigbare of onsigbare samelewing waargeneem word. Dit kom daarop neer dat daar 'n plek vir elke ding gevind en elke ding in 'n spesifieke plek gesien word.

\section{* Rites:}

As gevolg van die natuurlike 'aanval' op die 'grense' van mense se ordelike wêreld, konsentreer gemeenskappe hulle aandag en energie juis op hierdie 'grense' deur of deurentyd nuwe grense te vorm of om bestaande grense in stand te hou. Spesiale aandag word in mitologiese gemeenskappe aan rituele gegee om die invloed van die bose uit die samelewing te verdryf.

\section{* Liggaam:}

Die fisiese liggaam word gesien as 'n simbool van die sosiale liggaam. Die orde en kontrole met betrekking tot die sosiale liggaam word gerepliseer in die manier waarop die samehang van en die toegange tot die fisiese liggaam waargeneem en gekontroleer word.

\section{* Sonde:}

Sonde en afwyking word geassosieer met die formele oortreding van die reëls en wette van 'n sosiale groep. Sonde is 'n afwyking wat die sosiale liggaam besmet.

\section{* Kosmologie:}

Magte en kragte in die sigbare en onsigbare samelewing word antropomorfies verduidelik. So 'n persepsie spruit voort uit 'n dualistiese kosmos van vegtende magte van goed en sleg. Wanneer iets met iemand in só 'n mitologiese gemeenskap gebeur, is die onmiddellike vraag: wat vanuit die onsigbare wêreld het dit deur wie in die sigbare wêreld aan my gedoen?

\section{* Bose en ongeluk:}

In soverre die wêreld deur dualistiese magte van goed en sleg beïnvloed en bedreig word, is die wêreld 'n 'onregverdige' plek. Hierdie persepsie is die gevolg daarvan dat ongeluk nie aan persoonlike verantwoordelikheid toegeskryf word nie, maar aan die werking van kwaadwillige magte.

Bogenoemde sisteem kan gesien word as die wyse waarop die algemene simboliese universum ten tye van Jesus en die ontstaan van die Nuwe Testament daar uitgesien het. Hierdie algemene abstrakte persepsies moet egter vervolgens meer spesifiek en konkreet gemaak word. 


\subsection{Orde en chaos / Reinheid en besoedeling}

In haar boek, Purity and danger: An analysis of the concepts of pollution and taboo, het Mary Douglas (1966:35) voorgestel dat die konsep 'reinheid' binne die raamwerk van mitologiese gemeenskappe in simboliese terme gesien moet word. Vuilheid is volgens haar ' $n$ relatiewe term wat basies beteken dat iets nie 'in plek' is nie.

Die meeste sosiale groepe is daaraan gewoond om te midde van die chaos van die universum orde te skep. Hierdie ordening lei daartoe dat daar 'n plek vir elke ding gevind word en dat elke ding sodoende 'in plek' is. Douglas wys oortuigend daarop dat hierdie abstrakte sisteem van orde en klassifikasie met die konsep 'reinheid' te doen het. Reinheid is dus die term wat gebruik word om patrone van orde en klassifikasie mee te beskryf. Oor die algemeen gesien is 'n objek 'rein' wanneer dit konformeer met die norme wat die simboliese universum van 'n bepaalde kultuurgroep konstitueer. Besoedeling is wanneer ' $n$ saak of objek nie konformeer met die kulturele sisteem nie. Besoedeling het dus betrekking op sake wat 'uit plek' is. Om iets as vuil en besoedel te klassifiseer, impliseer met ander woorde dat mense dit waarneem as 'iets uit plek'. So gesien het reinheid met orde te doen en besoedeling met chaos. Wat die eerste-eeuse 'normatiewe Judaïsme' betref, vat Neyrey (1991:275) dit soos volg saam:

When we turn to first-century Judaism, the abstract notion of 'pure' and 'polluted' take on dramatic specificity. 'Pure' and 'polluted' are the precise words commonly used to label specific persons, places, and things; and their meaning derives from specific symbols and structures.

\subsection{Orde in die skepping en in die Israelitiese tempelgemeenskap}

\subsubsection{Die skepping}

Die God van Israel word volgens Levitikus 19:2 veral geken in terme van die konsep 'heiligheid' (kyk Douglas 1966:49). Die begrip 'heiligheid' druk die idee van afgesonderdheid uit. Heiligheid impliseer om op besonderse wyse 'in plek' te wees. Vir Israeliete beskryf die term 'heiligheid' God as die gans andere. Dit is een van die kernwaardes in die simboliese universum van die Israeliete. In terme van hierdie simboliese universum openbaar God sy heiligheid in sy skepping van 'n heilige/ordelike kosmos wat Hy seën.

Om te seën impliseer die legitimasie van orde (kyk Douglas 1966:50). Vanuit die perspektief van die geloofsbeskouing van die Israeliete is die primêre daad God se seën die skep van die kosmos. So gesien het ons dus twee sienings van God se heiligheid. God is eerstens 'heilig' omdat $\mathrm{Hy}$ as apart van dood en sonde (dit wil sê, verganklikheid) gesien moet word en tweedens omdat Hy orde uit chaos skep. Die skeppingsver- 
haal in Genesis 1 is soos 'n venster waardeur die wêreld van die eerste eeu as 'n ordelike wereld waargeneem kan word (vgl Neyrey 1988:76). In Genesis 1 kry ons die aanvoeling van die kartering of ordening van plekke, persone, tyd en dinge. God orden dinge in die ordelike kosmos deur hulle van mekaar te skei. Neyrey (1988:76) stel dit soos volg voor: God skep 'n reeks kaarte wat die wêreld orden, klassifiseer en definieer: 'What the creator God did in Genesis 1, then, defines the meaning of holy or "in place". What does not perfectly fit those categories, then, is unholy or unclean'. Hierdie beskouing stem ooreen met die insig van Mary Douglas (1966:41-57). Om die skepping in terme van kaarte voor te stel help dus om die verwysing van die begrip 'heiligheid' te verstaan. Vir die Israeliet kom dit daarop neer dat as die kaart nie gevolg word nie, besoedeling plaasvind. As dit wel gevolg word, dan is persone, tyd en plekke 'in plek' en daarom rein. In navolging van Douglas (1966:53-55) formuleer Neyrey (1988:76) dit soos volg: 'The issue lies in knowing the symbolic categories of the culture so as to know what does not fit them perfectly'.

\subsubsection{Die Israelitiese tempelgemeenskap}

Die tempel was die institusie in Israel ten tye van Jesus waar die simbole van orde op 'n baie duidelike wyse uitgedruk is (Douglas 1966:57; vgl ook Neyrey 1988:79). Die verskillende eerste-eeuse Judaïsmes (Saddusese, Farisese en selfs Esseense in terme van die 'normatiewe Judaïsme') het nie net die heiligheid van God abstrak in die skepping gesien nie, maar as konkreet uitgedruk in die Jerusalemse tempelsisteem. Die tempel en alles wat daarmee saamhang - tye, plekke, dinge en persone - was die konkrete strukturele uitdrukking van die kernwaarde van God se heiligheid. Neyrey (1991:277) formuleer dit soos volg:

This holiness came to be embodied especially in the central symbol of Israel's culture, the temple system, where spesific maps, replicating the patterns of Gen 1, regulated that focal system of the Jewish world, which was often thought to be the center of the universe.

Die wyse waarop hierdie simboliek van God se heiligheid deur die Sadduseërs tot uitdrukking gebring was, was egter nie kritiekloos deur almal in die eerste-eeuse Palestina aanvaar nie. Die Esseners, byvoorbeeld, het ernstige probleme gehad met die feit dat die Hasmoniese koninklike familie die tempelgemeenskap sedert die Makkabese orlog ter wille van eie belange beheer het. Hoewel daar met ander woorde 'n duidelike dominante sisteem was wat vir almal duidelik was, het almal nie in elke detail 
daarmee saamgestem nie. Volgens Van Aarde (1994:117) - in navolging van Anthony Saldarini - was daar byvoorbeeld in die tyd van Jesus 'n ernstige dispuutpunt tussen die Sadduseërs en die Fariseërs of die tempelmaatreëls ook in die alledaagse lewe behoort te geld.

\subsection{Kaarte en grenslyne}

Soos ons vroeër daarop gewys het, is die beginsel van 'n plek vir elke ding en elke ding in plek, konkreet gemaak deur spesifieke 'kaarte'. Ons het gesien dat besondere aandag gegee is aan lyne, grense en strukture om aan te toon waar elke persoon, plek en ding hoort. Reinheid kom neer op die presiese klassifikasie van persone, plekke en dinge. Daarom was daar groot kommer oor sake wat nie in 'n bepaalde definisie inpas nie en wat nie 'n presiese plek op 'n kaart het nie. In aansluiting by die werk van Jerome Neyrey - waarna ons reeds vroeër verwys het - verduidelik Dennis Duling die klassifikasie van die sisteem rein-onrein soos volg vanuit 'n antropologiese perspektief:

From an anthropological perspective classifications of 'clean,' 'holy,' 'pure,' or 'sacred' are made based on what is 'in place' according to social norms. Classifications of 'unclean,' 'defiled,' 'polluted,' or 'profane' are based on what is 'out of place'.

(Duling \& Perrin 1994:75)

Persone, plekke en dinge is rein as dit inpas in die sisteem. Wanneer dit egter die lyne oorskry en definisie vaag maak, begin dit uit plek beweeg. Sulke persone, plekke en dinge word gevolglik beskou as onrein en as gevaarlik en 'n bedreiging vir die samelewing omdat waarnemers nie seker is waar om dit in te orden nie. Neyrey (1991: 282) stel dit soos volg: " "Purity", then, has to do with system, order, and classification. It attends to correct labels and accurate definitions; it assigns appropriate physical space to things and people as well as their proper social location; it is concerned with completeness and wholeness'.

Vir die onderhawige studie oor Jesus se houding jeens die sondaars word die kaarte van persone baie belangrik, veral omdat dit op grond van die evangelies blyk dat Jesus hierdie kaarte nie gerespekteer het nie. Jesus het byvoorbeeld saam met mense geëet wat nie in hierdie kaarte ingepas het nie. Aan dooies, wat van die mees onrein dinge was, het Jesus gevat. Die moreel onreines was die voorwerpe van sy aandag. Hy het 
gereeld saam met tollenaars en sondaars geëet. Die fisiese onreines het insgelyks Jesus se volle aandag geniet. Jesus was gereeld in kontak met melaatses en daar is 'n tradisie van sy kontak met 'n menstruerende vrou. Die liggaamlik onvolmaaktes was ook die objek van sy bediening: kreupeles, blindes, siekes en duiwelbesetenes. Wat veral belangrik is, is dat Jesus aan hierdie mense wat fisies onvolmaak en onrein was, insluiting in die koninkryk van God aangebied het.

\subsection{Sondaars as 'mense uit plek'}

Die sosiale wêreld van die Judaïsmes in Jesus se tyd was 'n geordende wêreld. Ons het gesien dat dit dieselfde persepsie is wat aanleiding gegee het tot die skeppingstradisie in Genesis 1. Hierdie orde is konkreet uitgedruk in die tempelsisteem. Die tempel en die kaarte wat daarmee saamgaan, was die konkrete uitdrukking van die kernwaarde van Israel: God se heiligheid. Hierdie kernwaarde is in stand gehou deur reinheidsmaatreëls. Marcus Borg (1991:13) formuleer dit soos volg:

I argue that the dominant ethos of the Jewish social world in first-century Roman Palestine, its cultural paradigm or core value, was holiness understood as purity. Holiness generated a social world ordered as a purity system, with sharp boundaries not only between places, things, and times, but also between persons and social groups.

In die lig van hierdie sosiale sisteem kan ons sê dat die sondaars diegene was wat nie in die Israelitiese samelewing ingepas het nie. Die reinheidsisteem het hulle buite die aanvaarbare kaart van persone geklassifiseer. Dit wil sê, hulle was mense 'uit plek'. Die Jesus-beweging het egter hierdie reinheidsisteem uitgedaag en 'n alternatiewe interpretasie van die tora en die tempel aangebied:

As a social movement, it specifically included the impoverished and destitute, the sick and crippled, tax collectors, outcasts, and prostitutes. This egalitarian praxis was intended as an alternative ethos for Israel, subverting and intruding upon the dominant ethos. It was an alternative lifestyle not simply for individuals, but for a community.

(Borg 1991:10) 
Volgens Neyrey (1986) het Jesus sy invloed gebruik om gemarginaliseerde mense (tollenaars, sondaars, siekes) oor grense te lei - grense wat hulle as onrein, buitestaanders en sondaars geklassifiseer het. Jesus lei hulle oor die grense tot 'n nuwe status as vergewe, herstelde en gekose lede van God se verbondsgroep: 'Jesus' dealing with sinners and his healings deserve to be examined in the light of his role as a limit-breaking leader' (Neyrey 1986:110). Die sosiale dinamika van die vergifnis van 'n sondaar kom dus daarop neer dat Jesus aan mense 'uit plek' weer 'n plek op die kaart van persone en in die samelewing gegee het. Om met die woorde van Neyrey $(1986: 110)$ saam te vat: '... Jesus used his influence to lead marginal people across boundaries which classified them as unclean, outsiders, sinners into a new role as forgiven, restored, chosen members of God's covenant group'.

\section{GEVOLGTREKKING}

Ons het in die inleiding tot die onderhawige studie daarop gewys dat daar twee vrae is wat sentraal staan in die hedendaagse renaissance in Jesus-navorsing, naamlik Jesus en die eskatologie en Jesus se verhouding tot sy sosiale wêreld. Ons het ook gesien dat daar verskillende antwoorde deur Nuwe-Testamentici op hierdie vrae gegee word. Sanders is van mening dat Jesus 'n nabye toekomsverwagting gehad het. Borg aan die ander kant ontken dat daar 'n nabye toekomsverwagting in outentieke uitsprake van Jesus aanwysbaar is. 'In Borg's view Jesus did not proclaim the kingdom as as imminent future arrival of God's reign ...' (Smith 1989:75). Borg (1991:18) betoog daarom dat daar opnuut gekyk moet word na die verwysing van die woord eskatologie: einde van die fisiese wêreld? groot wêreldgebeure? interne gebeure in die lewe van die individu? enige siening wat 'n na-wêreldse lewe bevestig? teleologiese wyse?

'n Verwante vraag handel oor hoe ons die koninkryk van God in Jesus se boodskap moet verstaan. Verwys dit na die komende messiaanse ryk of na iets anders? Saam met die vraag na die eskatologiese gerigtheid van Jesus se boodskap al dan nie, moet die kwessie in verband met Jesus se betrokkenheid by sy sosiale wêreld gesien word. Sanders ontken dat Jesus se aktiwiteit enige sosiaal-politieke doel gehad het. In hierdie verband sê Smith (1989:74): 'Although Sanders understands Jesus to have envisioned a restoration eschatology in which Israel would center upon a new temple, he does not attempt to reconstruct the social and political circumstances out of which such a restoration eschatology would have developed'.

Borg en Neyrey, aan die ander kant, argumenteer dat sosiale betrokkenheid sentraal staan in Jesus se optrede en bedoelinge. Hiervolgens is Jesus se woorde en dade 'n protes teen die dominante etos van die Joodse sosiale wêreld en 'n bevestiging van 'n alternatiewe beskouing. 'Borg sees in the temple cult the incarnation of holiness as 
separation, which Jesus rejected' (Smith 1989:74). Die kontras tussen 'n sosiaal-politieke verstaan en 'n nabye eskatologiese verstaan van Jesus is groot. Vir die vraag na Jesus se houding jeens sondaars is dit van groot belang dat duidelikheid hieroor verkry word. As Jesus byvoorbeeld 'n nabye eskatologiese verwagting gehad het, kom vergifnis van sonde neer op ' $n$ eindtydelike gebeure en nie noodwendig as iets wat betekenis het vir die konkrete sosiale situasie van die sondaar se lewe van elke dag nie. Indien Jesus egter nie 'n nabye eskatologiese verwagting gehad het nie, beteken Jesus se bemoeienis met die sondaars dat Jesus iets vir hulle in hulle konkrete sosiale situasie hiér en nóú gedoen het. Vergifnis van sondes sou hiervolgens daarop neerkom dat Jesus aan mense 'uit plek' (dit wil sê, die sondaars) 'n plek in die sosiale wêreld van die eerste-eeuse Israelitiese gemeenskap gegee het. Dit sou beteken dat Jesus inderdaad 'n sosiale program gehad het.

Teenoor die moontlikheid dat Jesus 'n nabye eskatologie/nie 'n nabye eskatologie, dat Hy 'n sosiale program/nie ' $n$ sosiale program gehad het nie, is daar miskien nog ' $n$ derde moontlikheid: die moontlikheid dat Jesus sowel 'n nabye eskatologie as 'n sosiale program kon gehad het. Die gevolgtrekking waartoe Sanders gekom het - dat die 'sondaars' nie die עם הארצ was nie - dink ek is korrek. In terme van die bespreking van die sosiale wêreld van die eerste-eeuse Palestina kan ons die sondaars dus klassifiseer as 'mense uit plek'. Wat Sanders se standpunt oor die vergifnis van sonde betref, kan ek op grond van hierdie studie met hom saamstem dat Jesus nie op grond van die feit dat $\mathrm{Hy}$ sondaars vergifnis aangebied het, deur die priesterhoofde verwerp en doodgemaak is nie, maar op grond daarvan dat Hy verkondig het dat God die sondaars onvoorwaardelik aanvaar nog voordat berou betoon is. Die implikasie hiervan het Sanders egter nie uitgewerk en konkreet uitgedruk nie. Dit is soos Borg (1991:5) dit stel: 'Thus, although Sanders seeks to place Jesus firmly within a Jewish social world, Jesus ends up having very little to do with it. Jesus' relationship to it remains abstract, almost ideological.'

Dit is op hierdie punt waar die ondersoek na die sosiale wêreld van die eerste-eeuse Palestina ' $n$ groot bydrae lewer. Hiervolgens kom die vergifnis van sonde daarop neer dat Jesus aan mense 'uit plek' weer ' $n$ plek in die samelewing gegee het. Sodoende is die sosiaal uitgestotenes - diegene wat as 'sondaars' geëtiketteer is - deur God begenadig deurdat hulle God se teenwoordigheid in hulle lewens begin ervaar het.

\section{Literatuurverwysings}

Borg, M J 1988. A renaissance in Jesus-studies. Theology Today 55, 280-292.

- 1991. Portraits of Jesus in North American scholarship. HTR 84/1, 1-22.

Douglas, M T 1966. Purity and danger: An analysis of the concepts of pollution and taboo. London: Routledge \& Kegan Paul. 
Duling, D C \& Perrin, N 1994. The New Testament: Proclamation and parenesis, myth and history. Third edition. Orlando: Harcourt Brace College Publishers.

Dunn, J D G 1991. The parting of the ways: Between Christianity and Judaism and their significance for the character of Christianity. London: SCM.

Elliott, J H 1991. Temple versus household in Luke-Acts: A contrast in social institutions. HTS 47, 88-120.

Jeremias, J 1978. New Testament Theology, Volume one: The proclamation of Jesus, tr by J Bowden. London: SCM.

Kloppenborg, J S et al 1990. $Q$ Thomas reader. Sonoma: Polebridge.

Louw, J P \& Nida, E A 1988. Greek-English lexicon of the New Testament, Vol I \& 2. New York: UBS.

Malina, B J 1986. Christian origins and cultural anthropology: Practical models for Biblical interpretation. Atlantha: John Knox.

Neusner, J 1979. The way of Torah: An introduction to Judaism. 3rd Edition. North Scituate: Duxbury. (The religious life of man series.)

Neyrey, J H 1986. A biblical scholar's view of Christian origins and cultural anthropology. BTB 16/3, 107-110.

- 1988. Unclean, common, polluted, and taboo: A short reading guide. Foundations \& Facets Forum 4/4, 72-82.

1990. Paul in other words: A cultural reading of his letters. Louisville, Kentucky: Wesminster/John Knox Press.

- (ed) 1991. The social world of Luke Acts: Models for interpretation. Peabody, Massachusetts: Hendrickson.

Pienaar, P J H S 1989. Die sondaars in die tyd van Jesus en Paulus. BD-skripsie, Universiteit van Pretoria.

Sanders, E P 1985. Jesus and Judaism. London: SCM.

1992. Judaism: Practice and belief 63 BCE-66 CE. London: SCM.

Smith, D M 1989. A review of Marcus J Borg, Jesus: A new vision. Foundation \& Facets Forum 5/4, 71-82.

Van Aarde, A G 1988. Jesus en die sosiaal-veragtes. HTS 44/4, 829-846.

1989. Hand 7:48 - 'Die Allerhoogste woon nie in mensgemaakte konstruksies nie ...': Die relevansie van die Nuwe-Testamentiese wetenskap na aanleiding van die metafoor 'tempel'. Pretoria: Van Schaik. (Universiteit van Pretoria Nuwe Reeks Nr 259.)

- 1994. Kultuurhistoriese agtergrond van die Nuwe Testament: Die eerste-eeuse Mediterreense sosiale konteks. Pretoria: Kital.

Van Staden, P 1991. Compassion - the essence of life: A social-scientific study of the religious symbolic universe reflected in the ideology/theology of Luke. Pretoria: Perskor. (HTS Suppl 4.) 